\title{
Paulina Nowakowska* (iD https://orcid.org/0000-0001-5316-3872
}

e-mail: paulina.nowakowska577@gmail.com

\section{System przedsiębiorstwa innowacyjnego}

https://doi.org/10.25312/2391-5129.32/2021_04pn

\begin{abstract}
Stale rozwijający się rynek stawia wiele zadań oraz oczekiwań przed przedsiębiorcami, ale też oferuje coraz więcej możliwości. Jednak aby przedsiębiorstwo osiągało jak najwięcej zysków, musi sprostać ciągłym zmianom otoczenia rynkowego i opracowywać odpowiednie strategie. Celem artykułu jest przedstawienie rozwiązań na każdej płaszczyźnie przedsiębiorstwa, poczynając od produkcji i sięgając do zarządzania zespołem, oraz ukazanie korzyści wynikających z wprowadzania innowacji. Hipotezą zawartą we wstępie jest twierdzenie, że przedsiębiorstwo musi potrafić odpowiednio zarządzać innowacjami na każdym szczeblu działalności, by móc utrzymać się na rynku i być odpowiednio nastawionym na konkurencję oraz zmiany otoczenia.
\end{abstract}

Słowa kluczowe: innowacja, przedsiębiorstwo, strategia, zarządzanie, rynek, marketing

\section{Wstęp}

Według teorii ekonomii przedsiębiorstwo obiera sobie za cel maksymalizację zysków. Dąży ono do osiągnięcia stanu równowagi pomiędzy maksymalnym wykorzystaniem zasobów a najwyższym możliwym zyskiem ekonomicznym. Równowaga ta została zachwiana przez wprowadzenie do ekonomii pojęcia innowacji, które określa ciąg działań prowadzących do wytworzenia nowych bądź ulepszenia istniejących systemów organizacyjnych, produktów lub procesów technologicznych (Schumpeter, 1912). Przedsiębiorca, dążąc do zysku, wprowadza innowacje, które oddziałują

* Paulina Nowakowska - Uniwersytet Przyrodniczy w Lublinie, Wydział Inżynierii Produkcji, Studenckie Koło Naukowe Zarządzania i Ekonomii. 
między przedsiębiorstwem a rynkiem. Innowacja to szczególne narzędzie przedsiębiorców (Drucker, 1992), którego można się uczyć oraz praktykować.

Rozważając pojęcie innowacji, warto przytoczyć jeszcze definicję Mansfielda, który rozumie innowację w sposób zbliżony do pierwszego zastosowania wynalazku, oraz definicję Freemana, który kojarzy innowację z handlowym zastosowaniem wobec nowego produktu (Bielski, 2007). Z kolei Rogers (1962) innowację przyrównuje do wszystkiego, co jest postrzegane jako nowe.

Innowacje według Schumpetera to wszelkie zmiany w produkcji oraz dystrybucji. Wyróżniane przez niego trzy fazy w procesie zmian pokazane zostały na rysunku 1.

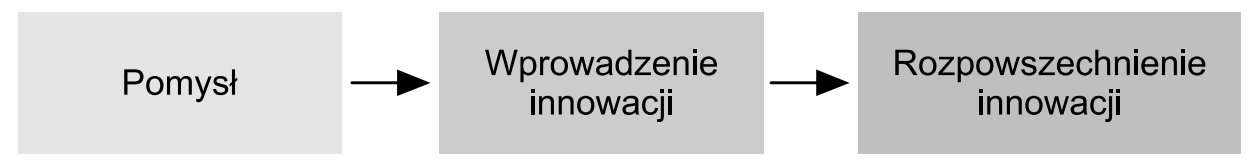

Rysunek 1. Trzy fazy wyróżniane w procesie zmian przez J.A. Schumpetera

Źródło: opracowanie własne na podstawie Innowacyjna teoria przedsiębiorstwa.

Do innowacji, które można wdrożyć w przedsiębiorstwie, zaliczamy:

- wprowadzenie na rynek nowego towaru/usługi,

- wprowadzenie nowych technologii,

- modernizację organizacji firmy - wewnątrz oraz na zewnątrz,

- optymalizację i ulepszenie istniejącego już produktu/usługi,

- nową metodę produkcji, która opierałaby się na nowych odkryciach, bądź ulepszoną produkcję działającą na dotychczas znanej wiedzy,

- nowe rynki zbytu (Schumpeter, 1960).

Podstawowymi funkcjami w przedsiębiorstwie są marketing i innowacja (Drucł ker, 1992), od których zależy przewaga nad konkurencją. Według J.A. Schumpetera konkurencja jest połączona z przedsiębiorczością, a sama przedsiębiorczość to umiejętność wprowadzania innowacji na rynek. Innowacje pozwalają przedsiębiorcom wyjść ponad konkurencję, co skutkuje wysokimi zyskami. „Tradycyjne firmy, które w porę nie umieją przestawić się i dostosować do nowych wymagań innowacyjnych, bankrutują bądź zostają wchłonięte przez nowych liderów rynkowych” (Semkow, 1988). Ciągłe wprowadzanie innowacji przez przedsiębiorstwa prowadzi do rozwoju technologicznego oraz gospodarczego. W przedsiębiorstwie innowacja zajmuje już konkretne miejsce, jest odpowiednio planowana oraz dostarcza odpowiednich efektów (Schumpeter, 1942).

Według OECD innowacja to wdrożenie nowego lub znacząco udoskonalonego produktu, usługi bądź procesu, a także nowej metody marketingowej/organizacyjnej, co łączy się z działaniem na relację przedsiębiorstwa z otoczeniem (National Innovation Systems, 1997).

Podział rodzajów innowacji został przedstawiony na rysunku 2. 


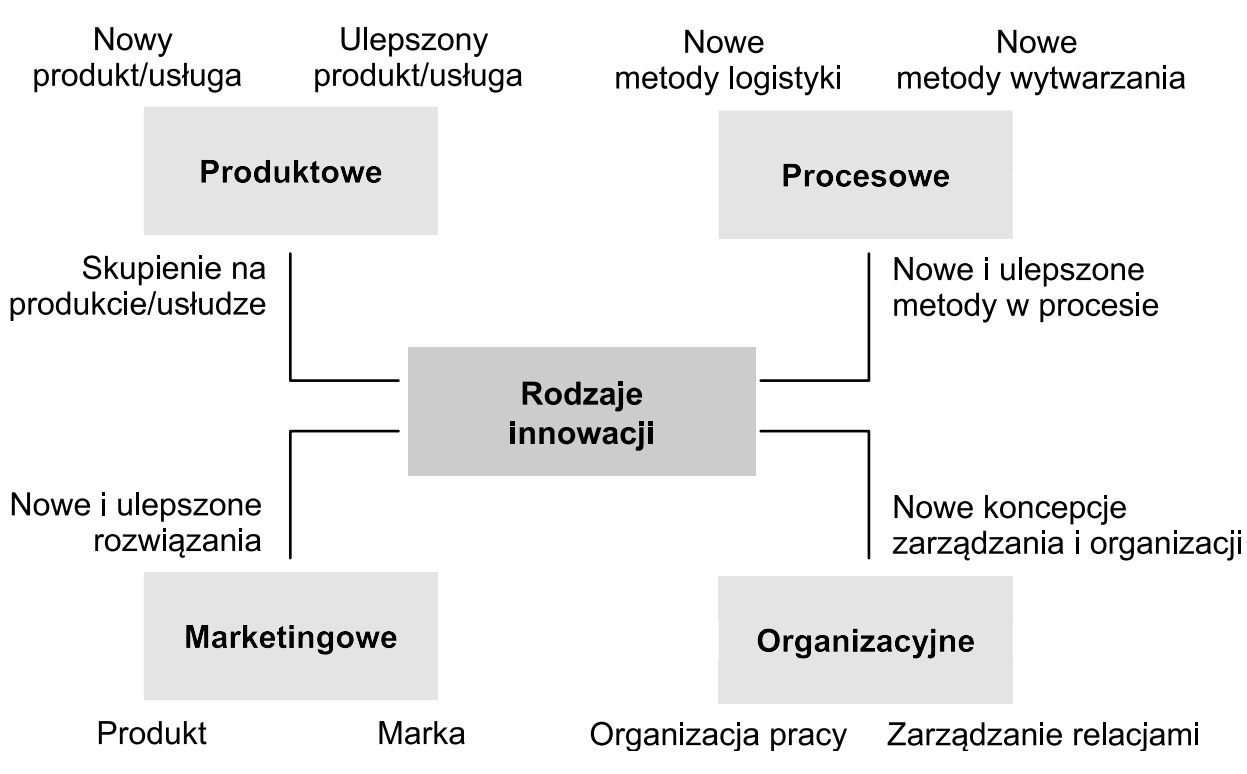

Rysunek 2. Cztery rodzaje rozwiązań innowacyjnych

Źródło: opracowanie własne na podstawie Nowacki, Staniewski, 2010: 16.

Celem artykułu jest przybliżenie informacji, pojęć oraz wiedzy z zakresu innowacyjności w przedsiębiorstwach. Hipotezą zawartą we wstępie będzie twierdzenie, że przedsiębiorstwo musi potrafić odpowiednio zarządzać innowacjami na każdym szczeblu działalności, by móc utrzymać się na rynku i być odpowiednio nastawionym na konkurencję oraz zmiany otoczenia. W opracowaniu wykorzystano dostępną w internecie analizę literatury oraz badań na potrzeby pracy o charakterze teoretyczno-empirycznym.

\section{Konkurencyjność przedsiębiorstw}

Innowacja to narzędzie wspomagające budowę konkurencyjnych strategii. Według badań przeprowadzonych przez R. Nowackiego polepszenie konkurencyjności firm znalazło się na czwartym miejscu w rankingu efektów innowacyjnych rozwiązań ${ }^{1}$.

W Encyklopedii Zarządzania dostępnej online konkurencyjność definiowana jest jako zdolność do konkurowania. Szerzej ujmując, są to działania prowadzące do zdobycia podobnych lub zbliżonych celów, o które zabiegają inne podmioty gospodarcze w takim samym czasie i otoczeniu. Konkurencyjność to także przetrwanie i działania w otoczeniu konkurencyjnym, oferowanie lepszego obrotu towarowego

${ }^{1}$ Badania z 2009 roku na ogólnopolskiej próbie 608 przedsiębiorstw w Polsce, zrealizowane przez R. Nowackiego (Nowacki, Staniewski, 2010: 19). 
niż konkurencja (Gorynia, 2000) oraz zdolność firm do innowacyjności w uzyskaniu przewagi nad konkurencją (Abbas, 2011).

Szybkie tempo procesów przemian współczesnego przedsiębiorstwa stawia konkurencyjność na jeszcze wyższym poziomie. Cała organizacja firmy musi skupić się nie tylko na rynku, ale także na wewnętrznych zmianach, jakie następują w firmach. Chris Zook wymienia kilka czynników, które jego zespół uważa za znaczące w gwałtownych przemianach biznesu:

- o wiele szybszy przepływ informacji, szybsza wymiana danych dotyczących konkurencji od cen i ofert po know-how,

- wzrost tempa mobilizacji i przepływu transz kapitału,

- częsty przepływ dyrekcji między firmami, co powoduje osłabienie ochrony przed konkurencją,

- tańsza konkurencja z Chin i Indii w wielu branżach,

- ciągły wzrost innowacji technologicznych, skrócenie cyklu rozwoju produktu (Zook, 2007).

Analiza rynkowa czy też analiza konkurencji pomaga dostarczyć firmie wymaganych informacji pozwalających zwiększyć przewagę konkurencyjną. Ponadto takie analizy umożliwiają firmie porównanie się z konkurencją czy dostosowanie się do wymagań społecznych. Obserwowanie otoczenia rynkowego jest bardzo ważne, ponieważ otoczenie to zmienia się w szybkim tempie, co niesie ze sobą różne istotne zmiany, na które przedsiębiorstwo powinno być odpowiednio przygotowane (Filipiak, 2019).

\section{Cele działalności innowacyjnej przedsiębiorstwa}

Działalność innowacyjna firmy może dotyczyć różnych sfer, na przykład produkcji wyrobu. Cele tej działalności zostały przedstawione na rysunku 3. Znalazły się wśród nich między innymi: większa konkurencyjność wyrobów na rynku, dostarczanie nowych usług oraz produktów na rynek czy też poprawa jakości i funkcjonalności usług i wyrobów.

Sfera działalności przedsiębiorstwa, jaką jest produkcja wyrobu, skupia się przede wszystkim na produkcie bądź usłudze oferowanej przez firmę dla klientów. We współczesnym świecie świadomość klientów na temat produktów i usług znacznie wzrosła, a to za sprawą tego, że na rynku dostępnych jest obecnie wiele firm oferujących podobne wyroby. Przedsiębiorstwa muszą stale dbać o to, żeby ich produkt był postrzegany jako lepszy od konkurencji. Innowacja produktowa to tworzenie i wprowadzanie na rynek towaru lub usługi, które są nowe bądź są ulepszoną wersją. O innowacji produktu stanowić mogą: specyfikacja techniczna, komponenty, materiały, wbudowane oprogramowania, łatwość obsługi i inne cechy decydujące o funkcjonalności danego produktu. 


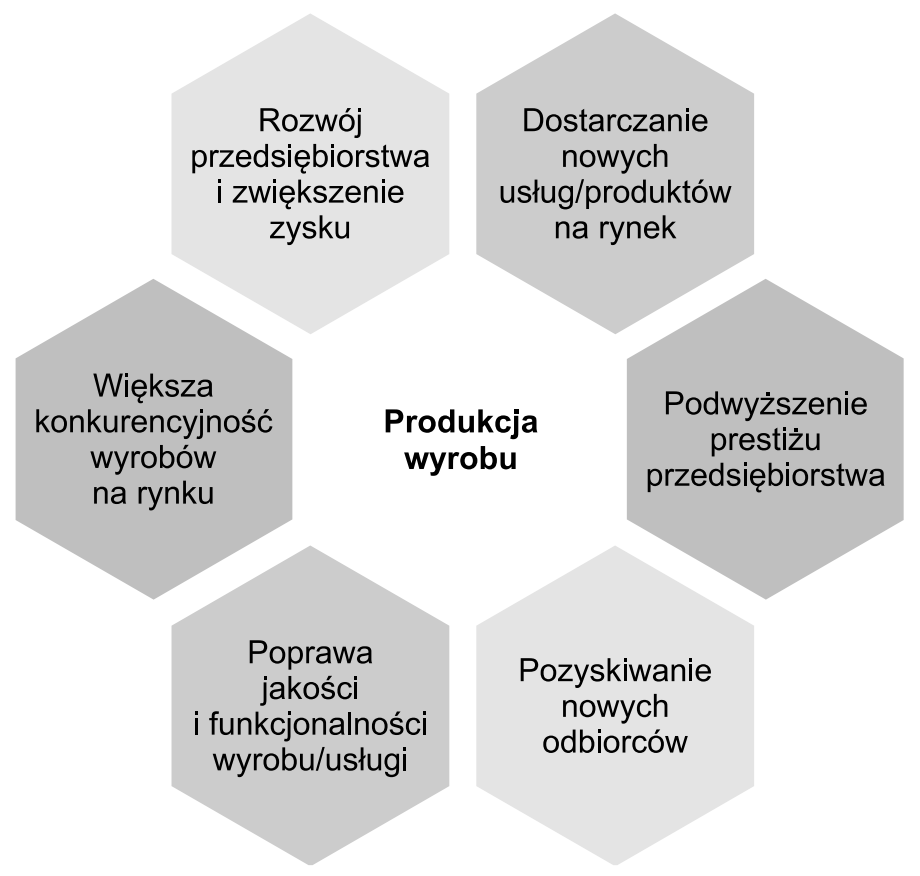

Rysunek 3. Cele działalności innowacyjnej w zakresie produkcji wyrobu

Źródło: opracowanie własne na podstawie Szatkowski, 2016: 31.

Tabela 1. Przykłady innowacji dóbr i usług

\begin{tabular}{|l|l|}
\hline \multicolumn{1}{|c|}{ Dobra } & \multicolumn{1}{c|}{ Usługi } \\
\hline $\begin{array}{l}\text { zmiany w produktach z dostosowaniem do } \\
\text { standardów ochrony środowiska }\end{array}$ & $\begin{array}{l}\text { usługi, które znacząco ulepszają dostęp } \\
\text { klientów do dóbr/usług (np. dowóz do domu) }\end{array}$ \\
\hline produkty ze zmniejszonym zużyciem energii & nowe formy gwarancji \\
\hline $\begin{array}{l}\text { produkty żywnościowe z dodatkowymi } \\
\text { cechami-funkcjami (np. margaryna } \\
\text { zmniejszająca poziom cholesterolu) }\end{array}$ & $\begin{array}{l}\text { karty magnetyczne i plastikowe (np. na } \\
\text { podstawie karty bankowej - łatwość dostępu) }\end{array}$ \\
\hline $\begin{array}{l}\text { zastępowanie materiałów komponentami } \\
\text { o lepszych parametrach (np. plastiki przyjazne } \\
\text { dla środowiska) }\end{array}$ & konta lojalnościowe (oferowanie rabatów) \\
\hline programowalne grzejniki & dostępność samoobsługi \\
\hline sprzęty domowe sterowane zdalnie & możliwość korzystania z usług przez internet \\
\hline
\end{tabular}

Źródło: opracowanie własne na podstawie Innowacja produktowa.

Gdy analizujemy przykłady innowacyjnych produktów przedstawione w tabeli 1, od razu nasuwają się pewne wnioski. U konsumentów wzrosła świadomość proekologiczna. Temu wyzwaniu muszą sprostać producenci, zapewniając, że zarówno produkcja, jak i użytkowanie oferowanego produktu nie ingeruje w środowisko naturalne albo w znacznie mniejszym niż dotychczas stopniu wpływa na nie. Klienci 
cenią sobie również niższe koszty eksploatacyjne - jak w przypadku produktów ze zmniejszonym zużyciem energii bądź wyrobów, które mogą nabyć taniej dzięki posiadaniu kart lojalnościowych. Wygoda to również czynnik współczesnego rynku. Ważny jest przede wszystkim łatwy dostęp do usług, na przykład przez internet. Duże znaczenie ma także udoskonalanie produktów poprzez wprowadzanie nowoczesnych technologii, jak w przypadku sprzętów domowych, które mogą być obsługiwane zdalnie z każdego miejsca i o każdym czasie.

Pozyskiwanie nowych odbiorców, jak i zwiększenie prestiżu przedsiębiorstwa to etap należący do marketingu firmy. Stale rosnąca popularność social mediów stwarza możliwość budowania swojej marki poprzez e-marketing. Social media marketing posiada własne narzędzia działania oraz formy reklamy. Jest to o wiele łatwiejsza i mniej wymagająca finansowo forma marketingu. Wizerunek firmy na portalach społecznościowych pozwala na budowanie stałych relacji z klientami, co przekłada się na zaufanie $\mathrm{z}$ ich strony. Tworzenie aktywnej społeczności firmy ułatwia zdobywanie cennych informacji na temat zapotrzebowania klientów, opinii o własnych produktach czy informacji o konkurencji (Social media, czyli promocja firmy w mediach społecznościowych, 2018).

\section{Technologia produkcji}

Stale rozwijające się technologie umożliwiają wdrażanie wielu zmian w sferze produkcji firm. Na rysunku 4 ukazane są struktury działalności w technologii produkcji firmy, które skupiają w sobie innowacyjne podejście.

Postęp technologiczny wpływa na proces produkowania dóbr oraz na oferowane usługi. Nowe technologie doprowadziły do rewolucji przemysłowej, czyli procesu zmian w technologii, gospodarce, społeczeństwie i kulturze. Zmiany te pozwoliły na przejście od produkcji rzemieślniczej i rolnictwa do produkcji mechanicznej w fabrykach. Pierwsza rewolucja przemysłowa (Przemysł 1.0) nastąpiła w XVIII wieku i opierała się na mechanizacji produkcji z wykorzystaniem maszyn parowych. Następnie Przemysł 2.0 skupiał się na masowej produkcji opartej na elektryfikacji maszyn i procesów technologicznych, zaś trzecia rewolucja przemysłowa (Przemysł 3.0) wprowadziła elektronikę i technologię IT do automatyzacji produkcji. Współcześnie powstała już koncepcja Przemysłu 4.0, która w 2011 roku w Niemczech została uznana za element strategii innowacyjnego rozwoju. Polega ona na przekształceniu fabryk w samoadaptujące, samowystarczalne i samoorganizujące się systemy (Piątek, 2017). 


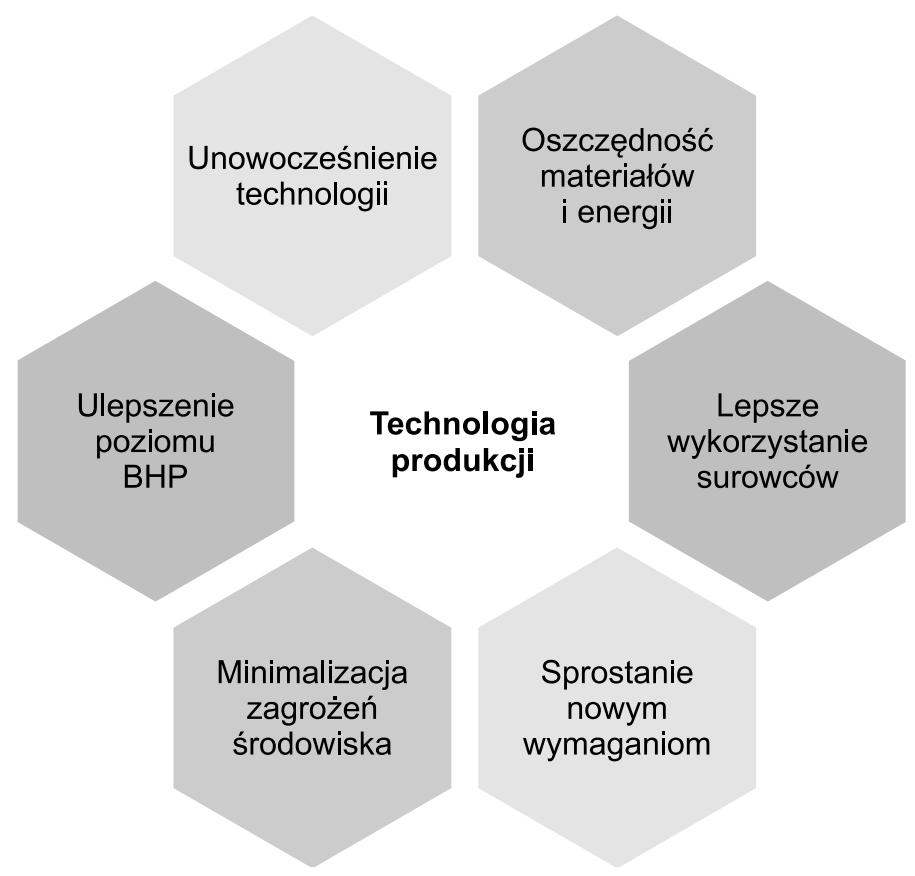

Rysunek 4. Sfera technologii produkcji oraz jej innowacyjne cele

Źródło: opracowanie własne na podstawie Szatkowski, 2016: 31.

W Polsce została przyjęta Ustawa z dnia 17 stycznia 2019 r. o Fundacji Platforma Przemysłu Przyszłości, czyli Przemysłu 4.0. Fundacja określiła następujące cele:

- tworzenie świadomości wśród przedsiębiorców i promowanie korzyści wynikających z cyfryzacji przemysłu oraz wykorzystania nowych technologii,

- proponowanie rozwiązań z zakresu transformacji cyfrowej przemysłu, zarządzania zmianą, wiedzą, innowacjami,

- wsparcie w zakresie podwyższenia poziomu technologicznego i organizacyjnego firm z naciskiem na procesy logistyczne, energetyczne oraz przetwórcze,

- szkolenia dla przedsiębiorców w zakresie cyfryzacji przemysłu,

- współpraca przedsiębiorstw nad projektami badawczymi związanymi z rozwojem inżynierii materiałowej, wprowadzaniem nowych produktów czy technik wytwarzania.

Dla przyszłości przedsiębiorstw niezbędne jest prognozowanie rozwoju technologii. Prognozowanie to przewidywanie przyszłych procesów oraz stanów dla otoczenia firmowego. Prognozowanie jest obarczone pewnym błędem, który jest zależny od metod prognozowania i wykorzystanych informacji. Prognozowanie technologii często odnosi się do:

- możliwości/granic technologii,

- zmian starej technologii na nowszą, 
- udziału technologii na rynku,

- przewidywania czasu pojawienia się nowych technologii oraz ich rodzaju (Santarek i in., 2016).

Decyzje podjęte w celu opracowania i wdrożenia nowych technologii oddziałują na organizację i jej działania, jej konkurencyjność, jak również na środowisko oraz społeczeństwo. Są to więc bardzo przyszłościowe aspekty do rozważań. Ocena skutków wprowadzania nowych technologii musi mieć swoje fundamenty w aspektach etycznych, w opinii społeczeństwa czy oddziaływaniu na środowisko (Santarek i in., 2016).

\section{Organizacja oraz zarządzanie}

Sfery działalności w dziale organizacji oraz zarządzania firmy zostały zaprezentowane na rysunku 5. Współczesne zarządzanie musi poszukiwać nowych wzorców i przejawiać nowoczesne podejście kierownicze w zakresie innowacji. Innowacja nie musi być kojarzona jedynie z ulepszeniami technologicznymi, jest nią także zmiana możliwości wykorzystania zasobów do tworzenia zysków.

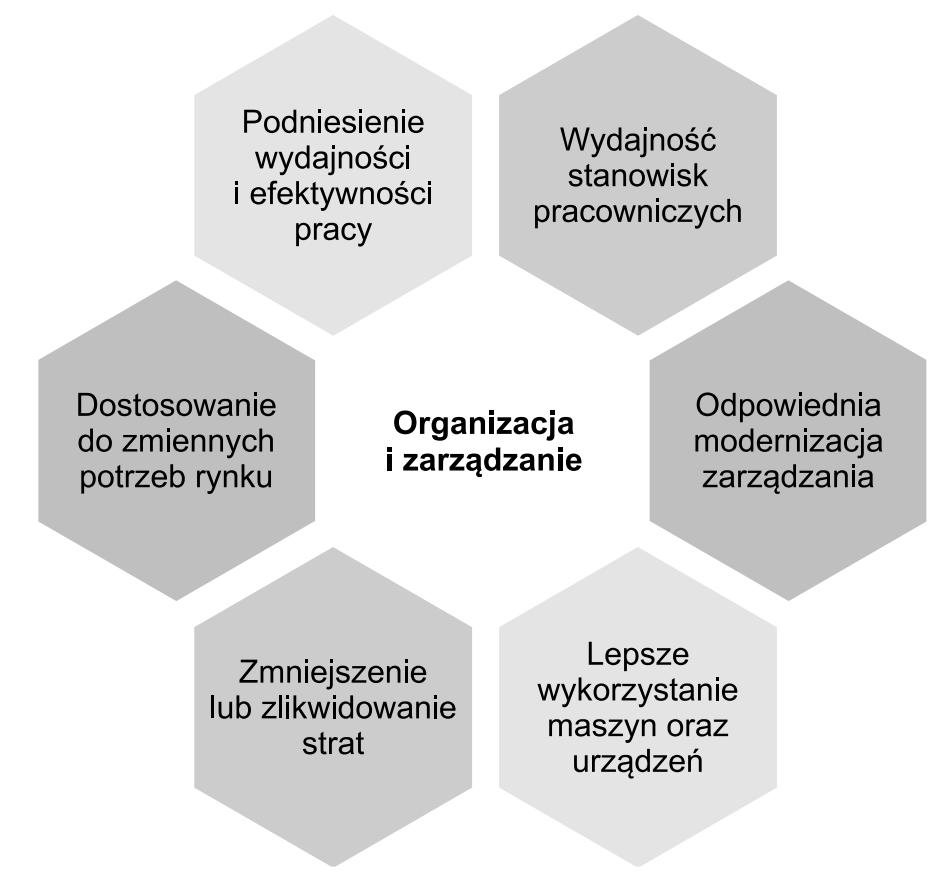

Rysunek 5. Sfera organizacji i zarządzania oraz jej innowacyjne cele

Źródło: opracowanie własne na podstawie Szatkowski, 2016: 31.

Według P.F. Druckera zmiany w organizacji oraz zarządzaniu innowacyjnym opierają się na siedmiu źródłach, które można podzielić na dwa zbiory: 
1. Aspekty związane ze zmianami w otoczeniu:
a) demografia,
b) zmiany w postrzeganiu oraz wartościach,
c) nowoczesna wiedza.

2. Źródła znajdujące się wewnątrz organizacji:
a) zmiany w strukturze przemysłu lub rynku,
b) innowacje powstające $z$ potrzeb procesu,
c) nieoczekiwane powodzenie/niepowodzenie; nieoczekiwane zdarzenie ze- wnętrzne,
d) niezgodności między rzeczywistością a wyobrażeniami (Drucker, 1992).

Nowoczesne koncepcje zarządzania skupiają się głównie na zasobach ludzkich. Rozwój kapitału składającego się z pracowników jest traktowany jako długoterminowa inwestycja przynosząca zyski. To właśnie kapitał ludzki w firmie ma największy wpływ na wyniki przedsiębiorstwa. Human Resource Management to metoda kierowania ludźmi w każdej organizacji, która stawia na pełne wykorzystanie potencjału pracowników, oferując im odpowiednie warunki w firmie. Zarządzanie ludźmi nie skupia się na usilnym dążeniu do osiągania korzyści dla firmy kosztem pracowników, ale na motywowaniu zatrudnionych i profilowaniu ich ścieżki kariery. Kluczowe dla firmy jest to, żeby pozyskać kompetentnych ludzi do pracy. Sam proces wyboru czy podpisania umowy to początki przysposobienia pracownika do firmy, kolejnymi etapami wdrażania powinna zajmować się kadra menedżerska, która będzie współpracować z ludźmi w firmie przez cały okres ich zatrudnienia. Odpowiada ona między innymi za motywację, odpowiedzialność czy obowiązkowość pracowników.

W HR (Human Resource Management) pojawiają się nowe trendy w organizacji, takie jak:

- wynagradzanie za kompetencje pracownika, zarządzanie kompetencjami,

- analiza i kształtowanie stanowisk oraz warunków pracy, komunikacja z pracownikami,

- marketing wewnętrzny, skupienie się na propozycjach pracowników,

- work-life balance, równowaga pomiędzy pracą a życiem prywatnym pracownika,

- skupienie się na ścieżkach kariery dla kadry pracowników, udoskonalanie ich kompetencji.

Zarządzenie firmą nie obejmuje jednak jedynie pracowników firmy. Jest to również odpowiednia organizacja, wprowadzanie nowych rozwiązań i kontrola całej sfery produkcji przedsiębiorstwa. W tym celu często wykorzystywane są następujące strategie zarządzania:

- benchmarking, który polega na porównaniu produktów, procesów i praktyk danej firmy z przedsiębiorstwami, które są uważane za najlepsze w danej dziedzinie, 
- lean manufacturing, stawiający za cel redukcję kosztów oraz marnotrawstwa, a jednocześnie oferujący najlepszy produkt oraz zwiększający dodatnie wartości udziału przedsiębiorstwa,

- inwestycje w sferę badawczo-rozwojową, innowacyjność i rozwój technologii w przedsiębiorstwie,

- algorytm MRP, tj. oprogramowanie umożliwiające kontrolę rodzajów, ilości i terminów w całej produkcji, jak również sterowanie zapasami oraz ich uzupełnianiem.

Wprowadzanie innowacji do firmy to główna część zarządzania oraz organizacji firmy. Innowacje wprowadza się, poczynając od wstępnej analizy rynku, analizy potrzeb klienta oraz analizy konkurencji. Dalsze etapy to całościowa ocena wiedzy i stanu technicznego organizacji, zdefiniowanie działań innowacyjnych, wyodrębnienie zespołu pracującego nad wdrażaniem innowacji, opracowanie koncepcji, projektów, ocena ekonomiczna. Po tych etapach następuje decyzja oraz realizacja przedsięwzięcia innowacji w firmie (Santarek i in., 2016).

\section{Innowacja a korzyści}

Przedsiębiorstwo, stawiając na rozwój przy odpowiednich założeniach i udanych próbach wdrażania innowacji, może spodziewać się wielu korzyści na każdej płaszczyźnie działalności. Kilka z nich wymienionych zostało w tabeli 2.

Tabela 2. Korzyści związane z innowacjami przedsiębiorstwa

\begin{tabular}{|l|l|}
\hline Korzyści strategiczne & $\begin{array}{l}\text { - większy udział na rynku } \\
\text { - wejście na nowe rynki } \\
\text { - realizacja strategii }\end{array}$ \\
\hline $\begin{array}{l}\text { Korzyści produktowe/ } \\
\text { produkcyjne }\end{array}$ & - nowe miejsca pracy \\
\hline $\begin{array}{l}\text { Korzyści } \\
\text { z usprawnień } \\
\text { technologicznych }\end{array}$ & $\begin{array}{l}\text { - na przykład zastąpienie pracy człowieka maszyną, co może } \\
\text { przyśecesy produkcyjne }\end{array}$ \\
\hline Korzyści rynkowe & $\begin{array}{l}\text { - niższe ceny } \\
\text { - elastyczność i atrakcyjność } \\
\text { - zadowolenie klientów } \\
\text { - silne relacje z klientami } \\
\text { - zróżnicowanie oferty na rynku }\end{array}$ \\
\hline Korzyści operacyjne & $\begin{array}{l}\text { - niskie koszty bezpośrednie } \\
\text { - odpowiednia precyzja } \\
\text { - dokładność } \\
\text { - lepsze wykorzystanie aktywów }\end{array}$ \\
\hline
\end{tabular}




\begin{tabular}{|c|c|}
\hline Korzyści podatkowe & $\begin{array}{l}\text { - skrócenie czasu amortyzacji zakończonych prac badawczo- } \\
\text {-rozwojowych z } 36 \text { do } 12 \text { miesięcy } \\
\text { - odliczenie od podstawy opodatkowania wydatków na zakup nowej } \\
\text { technologii od jednostek naukowych w wysokości } 50 \% \text { ceny } \\
\text { zakupu nowej technologii w przypadku mikro, małych i średnich } \\
\text { przedsiębiorstw, } 30 \% \text { w przypadku pozostałych podmiotów } \\
\text { - zaliczenie wydatków na prace badawczo-rozwojowe w koszty } \\
\text { uzyskania przychodów niezależnie od wyniku prac - jedyny warunek to } \\
\text { zakończenie tych prac }\end{array}$ \\
\hline Korzyści ogólne & $\begin{array}{l}\text { - podniesienie prestiżu przedsiębiorstwa } \\
\text { - zdobywanie rynków } \\
\text { - większe zyski } \\
\text { - unowocześnienie technologii } \\
\text { - dostosowywanie się do obowiązujących norm na przykład z zakresu } \\
\text { bezpieczeństwa, ochrony środowiska } \\
\text { - poprawa warunków pracy } \\
\text { - wzmacnianie marki } \\
\text { - dodatkowa wiedza i kompetencje } \\
\text { - rozwój ekosystemu }\end{array}$ \\
\hline
\end{tabular}

Źródło: opracowanie własne na podstawie Korzyści z wdrażania innowacji, 2015; Hammer, 2004: 5.

Główne korzyści dla przedsiębiorstw to przede wszystkim większe udziały na rynku, ponieważ dzięki temu zyskują silne relacje z klientami zarówno stałymi, jak i nowymi oraz zwiększają atrakcyjność firmy na tle innych.

\section{Priorytety przedsiębiorstw na tle epidemii koronawirusa}

Epidemia COVID-19 zmusiła wiele firm do nowego opracowania swoistych strategii. Nawet po zakończeniu pandemii przedsiębiorstwa będą dalej toczyły długą walkę ze skutkami tego wydarzenia. Postpandemiczna rzeczywistość kształtuje już jednak wśród przedsiębiorstw nowe priorytety, w jakie chcą inwestować i według których chcą prowadzić działalność (International Data Corporation, 2020). Pierwszym z nich jest zbudowanie środowiska cyfrowego dla pracowników. Epidemia doprowadziła wiele firm do zamknięcia, tam, gdzie było to możliwe, zostały wprowadzone stanowiska pracy zdalnej w warunkach domowych. Po wybuchu COVID-19 odsetek pracowników pracujących zdalnie wynosił 45\%, podczas gdy wcześniej plasował się przeciętnie na poziomie 14\% (Computerworld, 2020). Konieczna stała się reorganizacja wewnętrzna przedsiębiorstw, żeby mogły one sprostać wymaganiom wobec pracowników zdalnych. Druga ważna inicjatywa związana ze zmianą warunków otoczenia to nastawienie przedsiębiorstwa na problemy i rozwiązania ze szczególnym uwzględnieniem nowych wymagań klienta. IDC (International Data Corporation) szacuje, że do następnego roku 40\% czasu, który był konsumowany na rozwój i tworzenie oprogramowania, zostanie poświęcone na modyfikację aplikacji oraz usług, by konsumenci mogli realizować transakcje i korzystać z usług w sposób szybki oraz niewymagający bezpośredniego kontaktu. Trzecim priorytetem według 
IDC jest nacisk na automatyzację w przedsiębiorstwach. Ma to umożliwić korzystanie na przykład ze wsparcia „cyfrowych współpracowników” (Computerworld, 2020), którymi byłaby sztuczna inteligencja, zwiększająca efektywność działania firmy.

Pandemia postawiła przedsiębiorstwa przed nowym wyzwaniem. Jedno z ostatnich badań IDC pokazuje, że aż $42 \%$ osób decyzyjnych w zakresie zakupu technologii planuje inwestycje i innowacje w obszarze transformacji cyfrowej (International Data Corporation, 2020). Takie dane z przeprowadzanych badań potwierdzają, że przedsiębiorstwa innowacyjne odczuwają potrzebę wdrożenia nowych technologii, aby móc dalej dobrze prosperować na rynku. Kolejnym nasuwającym się wnioskiem jest to, że innowacyjność jest uzależniona od otoczenia w danym momencie.

\section{Podsumowanie}

W dzisiejszych czasach następuje kumulacja bodźców płynących z otoczenia rynkowego, na które składają się szybkie tempo postępu technologicznego, duży napływ wielu informacji oraz nieprzewidywalne sytuacje związane ze zmianą środowiska, takie jak pandemia COVID-19, która sparaliżowała rynek i postawiła nowe wymagania wobec przedsiębiorców. Najważniejszym czynnikiem sukcesu przedsiębiorstw jest odpowiednie nastawienie na konkurencję i wychwytywanie słabości firmy na rynku (Sajdak, 2013). Niestabilne otoczenie obliguje przedsiębiorców do ciągłego tworzenia rozwiązań i podejmowania działań pozwalających uporać się ze zmianami w różnych dziedzinach oddziałujących na firmę. Innowacyjność firmy to nie tylko wprowadzanie nowych technologii, ale także odpowiednia organizacja w takich obszarach, jak produkcja, marketing, sprzedaż, relacje z pracownikami, warunki pracy. Bardzo ważna w dzisiejszych czasach jest opinia firmy wśród klientów. Powstaje ona na podstawie tego, jak działa firma od środka, jak przebiega produkcja od początkowych etapów, jak traktowani są pracownicy oraz co otrzymują klienci i czy zakupione produkt czy usługa spełniają ich oczekiwania. Przedsiębiorstwa muszą zachować równowagę w zakresie innowacyjności, żeby nie narazić żadnej ze struktur działania firmy.

\section{Bibliografia}

Abbas A.J. (2011), Strategic Management: Concept \& Cases, Pearson, South Carolina.

Bielski I. (2007), Innowacje w kreowaniu zdolności konkurencyjnej przedsiębiorstwa, Uniwersytet Technologiczno-Przyrodniczy im. Jana i Jędrzeja Śniadeckich w Bydgoszczy, Bydgoszcz.

Brzeziński M. (red.) (2001), Zarzadzanie innowacjami technicznymi i organizacyjnymi, Difin, Warszawa. 
Christensen C.M. (1997), The Innovator's Dilemma. When New Technologies Cause Great Firms to Fail, Harvard Business School Press, Boston.

Computerworld, https://www.computerworld.pl/ [dostęp: 13.02.2021].

Drucker P.F. (1992), Innowacja i przedsiębiorczość. Praktyka i zasady, PWE, Warszawa.

Filipiak (2019), Restrukturyzacje w Polsce. Raport Roczny za 2018 r., http://zimmermanfilipiak.pl/aktualnosci/prezentacje/restrukturyzacje-w-polsce-raport-roczny-za-2018-r.html [dostęp: 19.01.2022].

Gorynia M. (2000), Zachowania przedsiębiorstw w okresie transformacji. Mikroekonomia przejścia, Wydawnictwo Akademii Ekonomicznej w Poznaniu, Poznań.

Hammer M. (2004), Transformacja firmy poprzez innowacje operacyjna, „Harvard Business Review Polska: siła nowych idei”, nr 5.

Innowacja produktowa, [w:] Encyklopedia Zarzadzania, https://mfiles.pl/pl/index. php/Innowacja_produktowa [dostęp: 10.02.2021].

Innowacyjna teoria przedsiębiorstwa, [w:] Encyklopedia Zarzadzania, Innowacyjna teoria przedsiębiorstwa - Encyklopedia Zarzadzania (mfiles.pl) [dostęp: 10.02.2021].

Konkurencyjność, [w:] Encyklopedia Zarzadzania, Konkurencyjność - Encyklopedia Zarzadzania (mfiles.pl) [dostęp: 10.02.2021].

Korzyści z wdrażania innowacji (2015), https://www.oswiata.rzeszow.pl/upload/projektyunijne/BROSZURA.pdf [dostęp: 10.02.2021].

National Innovation Systems (1997), https://www.oecd.org/science/inno/2101733. pdf [dostęp: 10.02.2021].

Nowacki R., Staniewski M. (red.) (2010), Znaczenie innowacyjności w rozwoju przedsiębiorstwa, [w:] tegoż, Podejście innowacyjne w zarządzaniu przedsiębiorstwem, Difin, Warszawa.

Pałucha K. (2015), Wdrażanie innowacji $w$ obszarze organizacji i zarzadzania elementem wptywającym na wzrost konkurencyjności przedsiębiorstw, Politechnika Śląska, Instytut Zarządzania i Administracji.

Piątek Z. (2017), Czym jest Przemyst 4.0?, https://przemysl-40.pl/index. php/2017/03/22/czym-jest-przemysl-4-0/ [dostęp: 29.03.2021].

Sajdak M. (2013), Koncepcja zwinności w ksztattowaniu konkurencyjności przedsiębiorstw, „Management Forum”, nr 4.

Santarek K., Lipski J., Świć A., Piekarski W., Dudziak A., Stoma M., Paszek A., Wittbrodt P. (2016), Innowacyjne technologie w inżynierii produkcji, Politechnika Lubelska, Lublin.

Schumpeter J. (1912), The Theory of Economic Development, Harvard Economic Studies.

Schumpeter J. (1942), Creative Destruction - Capitalism, Socialism and Democracy, Harper\&Bros, New York. 
Schumpeter J. (1960), Teorie rozwoju gospodarczego, PWN, Warszawa.

Semkow J. (1988), Śladami wielkich ekonomistów, PWN, Warszawa.

Social media, czyli promocja firmy w mediach społecznościowych (2018), Poradnik Przedsiębiorcy, https://poradnikprzedsiebiorcy.pl/-social-media-czyli-promocja-firmy-w-mediach-spolecznosciowych [dostęp: 29.03.2021].

Szatkowski K. (2016), Zarzadzanie innowacjami i transferem technologii, Wydawnictwo Naukowe PWN, Warszawa.

Ustawa z dnia 17 stycznia 2019 r. o Fundacji Platforma Przemysłu Przyszłości, Dz.U. 2019, poz. 229.

Zook Ch. (2007), Unstoppable: Finding hidden assets to renew the core and fuel profitable growth, Harvard Business School Press.

\section{Summary \\ Innovative enterprise system}

The constantly developing market sets many tasks and expectations for entrepreneurs, but also offers an increasing number of opportunities. However, in order for a company to achieve maximum profits, it has to cope with the constant changes of the market environment and develop appropriate strategies.

The aim of this article is to present solutions at every level of the company, starting from production and extending to team management, and to show the benefits of introducing innovations.

Keywords: innovation, enterprise, strategy, management, market, marketing 